\title{
ASSOCIATION OF ANTHROPOMETRIC, PHYSIOLOGYCAL AND PHYSICAL TRAITS TO SUCCESS OF ELITE MALE MOUNTAIN CLIMBERS
}

\author{
Hamid Arazi, Tahmineh Saeedi, Mani Izadi \\ University of Guilan, Department of Exercise Physiology, Iran
}

\begin{abstract}
The purpose of this study was to examine the anthropometric, physiological and physical traits of elite mountain climbers and relationship of these traits to success in mountain climbing. Thirty-eight elite male Iranian mountain climbers (height of $178.68 \pm 5.77 \mathrm{~cm}$, body mass index of $23.4 \pm 2.78 \mathrm{~kg} / \mathrm{m}^{2}$ and age of $31.26 \pm 6.93$ years) were assessed for some anthropometric, physiological and physical variables. So that, height, weight, and also length and circumference of limbs were measured. Percent body fat was determined by 3 sites measurements of skin-folds thickness. Aerobic power was assessed via a 12-minute run, anaerobic power was determined using anaerobic step test, Vertical and horizontal jump performance were evaluated with Sargent jump and standing long jump tests respectively, 40 yard dash was used to assess speed, and muscular endurance of torso and upper body were evaluated using sit-ups and push-ups tests. The sum of scores related to sport achievements was considered as the criterion evaluating success of mountain climbers. Anthropometric traits (only age and percent body fat) showed a poor positive relationship $(\mathrm{p}<0.05)$ with success. Whilst there were relatively strong relationship between physiological and physical traits including aerobic power $(\mathrm{p}<0.01)$, anaerobic power $(\mathrm{p}<0.01)$, vertical jump $(\mathrm{p}<0.05)$, lower body strength $(\mathrm{p}<0.01)$ and muscular endurance of torso $(\mathrm{p}<0.05)$ and upper body $(\mathrm{p}<0.01)$ with success of mountain climbers. Results indicate the importance of physiological and physical traits compared to anthropometric traits of mountain climbers and successful climbing depends largely on aforementioned characteristics.
\end{abstract}

Key words: ALTITUDE/ MOUNTAIN CLIMBING/ PHYSIOLOGYCAL TRAITS/ PERFORMANCE

\section{INTRODUCTION}

It has been shown that elite athletes should have special anthropometric, physiological and physical traits related to their own sport. Accordingly, having specific physique, and also top physiological and physical capabilities can be considered as the key factors to success in sport events. An awareness of those abilities required in sport and implementation of talent identification based on them may raise the possibility of success in sport events. Therefore, the main and the most important obligation of coaches, specialists and consultants is detection of talents based on the factors which required in each sport (Barbieri, Zaccagni, Cogo, \& Gualdi-Russo, 2012; Claessens, Lefevre, Beunen, \& Malina, 1999).
Understanding the importance of nature, situations, and also necessary anthropometric and physiological characteristics of any sport is vital for optimizing performance. Training programs must therefore be planned regarding such variables. Lack of attention to required attributes of sport may lead to a waste of time and funding (Cheung et al., 2011; Gualdi-Russo \& Zaccagni, 2001). Surely, such attributes may have role in athletic success. The question is whether these attributes work in related sports.

Mountain climbing which has been initially done as a recreational activity, some advanced techniques and strategies have been introduced to improve health over time (Grant et al., 2001; Kemmler et al., 2006). International Council for Competition Climb- 
ing (ICC) is also responsible for organizing Competitive sport climbing (Sheel, 2004). It is interesting to note that after holding the Olympic Games in Mexico City, much attention was paid to the altitude and performance in such conditions (Daniels, 1979).

A study was done with emphasis on anthropometric changes in 8 women induced by long-term exposure to high altitude $(4,297 \mathrm{~m})$. Authors reported significant changes in percent body fat and circumference of extremities with little change in body mass. Results reflected decreased percent body fat during high altitude residence (Hannon, Shields, \& Harris, 1969).

Another research investigated the changes in body composition and anthropometric variables in 18 subjects (10 males and 8 females). The changes were considered regarding 3 phases (before departure from sea level, during climbing, and after return to sea level). Men showed a higher decrement in percent body fat than women. In men, baseline levels of fat mass positively and negatively related to decrement in fat mass and fat free mass, respectively (Zaccagni, Barbieri, Cogo, \& Gualdi-Russo, 2014).

A case study was carried out on the climber went to ascend two mountain tops (Aconcagua $(6,962 \mathrm{~m})$ and Everest $(8,848 \mathrm{~m})$ ). Physical changes were measured several days after departure. Results demonstrated a $3 \%$ and $21.9 \%$ decrease in body mass and percent body fat after Aconcagua expedition. Similarly, a $6.9 \%$ and $41 \%$ decrease in mentioned variables were shown after Everest expedition. The longer exposure to altitude in Everest expedition appears to be possible cause of more physical changes (Wagner, 2010).

Nevertheless, although much research has been done on climbers, most of them have investigated the effect of hypoxia on performance in sea level and altitude and less attention has been paid on anthropometric, physiological and physical traits and their relationship to performance. Thus, the present study aimed to investigate the anthropometric, physiological and physical traits of elite mountain climbers and relationship of these traits to success in elite mountain climbers.

\section{METHOD}

\section{Participants}

The sample consisted of 38 elite male Iranian mountain climbers involved in mountain climbing professionally and on average one climb to tops above
3,000 m per week. Institutional ethical approval was granted. Afterward, subjects were informed about protocol.

\section{Anthropometric assessment}

Anthropometric variables including height, lower body length, and also chest, waist, thigh and calf circumferences were measured to the nearest $0.1 \mathrm{~cm}$. Weight was also measured to the nearest $0.1 \mathrm{~kg}$ with a digital scale. Body mass index was calculated by dividing weight $(\mathrm{kg})$ by height $(\mathrm{m})$ squared $\left(\mathrm{kg} / \mathrm{m}^{2}\right)$. Subcutaneous body fat was measured at 3 sites (Chest, Abdominal and Thigh) using Vogel caliper (made in Germany), and then percent body fat was calculated through Jackson and Pollock equation (1978) (Beam \& Adams, 2013; Jackson \& Pollock, 1978).

\section{Physiological assessment}

In this study, the 12-minute run test was used to determine maximal aerobic power. The subjects were asked to run with possible speed in 12 minutes and $\mathrm{VO}_{2 \max }$ was estimated using following equation in order to assess aerobic power (Beam \& Adams, 2013):

$$
\mathrm{VO}_{2 \max }(\mathrm{ml} / \mathrm{kg} / \mathrm{min})=(\text { Distance }(\mathrm{km})-0.505) \div
$$

The anaerobic power was determined using anaerobic step test. The results were calculated with following equation (Beam \& Adams, 2013):

$\mathrm{M}-\mathrm{Anp}(\mathrm{W})=\left({ }^{+} \mathrm{W} \times 1.33\right) \div \mathrm{t}$

M-Anp : mean anaerobic power; ${ }^{+} \mathrm{W}$ : positive work (force $\times$ distance); force : body mass $(\mathrm{N})$; distance $=$ bench height $(0.4 \mathrm{~cm}) \times$ steps (in 1 minutes); 1.33 : the factor converting positive work to total work (N.m;j); t : $60 \mathrm{~s}$

\section{Physical assessment}

Vertical and horizontal jump performance were evaluated with Sargent jump and standing long jump tests and through scaled wall and ground, respectively. Plus, Speed was assessed via 40 yard dash. Time to completion of test was recorded with Q\&Q chronometer. Leg press test was used to assess maximal strength of lower body muscles so that subjects completed maximal repetitions until failure. Then, 1RM was calculated using Brzycki equation (Brzycki, 1993). Sit-ups and push-ups tests were used to determine muscular endurance of torso and upper body, respectively. In push-ups test the maximal repetitions were performed to failure. While, subjects were in- 
structed to complete sit-ups in 1 minute and number of repetitions was recorded.

\section{Quantifying achievements}

Some sports discipline regarding their own nature may not allow to quantify athletic results, and mainly there is no certain competition for them. There- fore, valuation is difficult and this is quite evident in mountain climbing. Accordingly, after consultation with related specialists and referral to accomplished researches, the success of climbers was considered based on the scores determined by Federation and the entire scores of them in mountain climbing. The valuation is present in table 1 .

Table 1. Valuation method for success based on achievements in elite climbers

\begin{tabular}{ccc}
\hline Height $(\mathbf{m})$ & Equal to & Score \\
\hline $8501-8848$ & $1^{\text {st }}$ World rank & 100 \\
$8101-8500$ & $2^{\text {nd }}$ World rank & 90 \\
$7901-8100$ & $3^{\text {rd }}$ World rank & 85 \\
$7601-7900$ & $1^{\text {st }}$ Asia rank & 80 \\
$7301-7600$ & $2^{\text {nd }}$ Asia rank & 70 \\
$7001-7300$ & $3^{\text {rd }}$ Asia rank & 65 \\
$6601-7000$ & $1^{\text {st }}$ Country rank & 60 \\
$6101-6600$ & $2^{\text {nd }}$ Country rank & 50 \\
$5501-6100$ & $3^{\text {rd }}$ Country rank & 45 \\
\hline
\end{tabular}

\section{Data analyses}

The normality of data distribution was determined by Kolmogorov-Smirnov test and the Pearson correlation coefficient was used to determine the relationship of anthropometric, physiological and physical traits to success. All statistical analyses were performed using SPSS 20. The significance level was set at $\mathrm{p}<0.05$.

\section{RESULTS}

Descriptive statistics of anthropometric, physiological and physical traits of subjects, and also their relationship with success are shown in table 2. 
Table 2. Results of correlation related to anthropometric, physiological and physical traits to success in elite male climbers

\begin{tabular}{lccc}
\hline \multicolumn{1}{c}{ Variable } & Mean \pm SD & r & p \\
\hline Age (years) & $31.26 \pm 6.93$ & 0.37 & $0.01^{*}$ \\
Body mass (kg) & $74.51 \pm 7.80$ & 0.15 & 0.18 \\
Body height (cm) & $178.68 \pm 5.77$ & 0.03 & 0.42 \\
Lower body length (cm) & $102.72 \pm 4.99$ & 0.06 & 0.34 \\
BMI(kg/m $)$ & $23.40 \pm 2.78$ & 0.10 & 0.25 \\
Percent body fat & $12.10 \pm 0.039$ & -0.28 & $0.04^{*}$ \\
Girth of chest (cm) & $95.30 \pm 6.75$ & 0.23 & 0.07 \\
Girth of waist (cm) & $85.24 \pm 6.34$ & 0.02 & 0.45 \\
Girth of thigh (cm) & $54.86 \pm 4.12$ & 0.22 & 0.08 \\
Girth of calf (cm) & $37.87 \pm 4.47$ & 0.03 & 0.42 \\
VO mimax mg/min & $44.25 \pm 7.37$ & 0.38 & $0.009^{* *}$ \\
Anaerobic power (W) & $389.99 \pm 103.06$ & 0.48 & $0.001^{* *}$ \\
Vertical jump (cm) & $44.26 \pm 6.44$ & 0.33 & $0.02^{*}$ \\
Long jump (cm) & $222.18 \pm 18.94$ & 0.04 & 0.4 \\
Run 40 yards (s) & $8.31 \pm 1.47$ & -0.14 & 0.18 \\
Leg press 1RM (kg) & $93.03 \pm 13.97$ & 0.42 & $0.004^{* *}$ \\
Torso muscular endurance (reps) & $43.37 \pm 13.48$ & 0.31 & $0.02^{*}$ \\
Upper body muscular endurance (reps) & $37.26 \pm 19.95$ & 0.38 & $0.008^{* *}$ \\
\hline
\end{tabular}

${ }^{*} \mathrm{p} \leq 0.05 ;{ }^{* *} \mathrm{p} \leq 0.01$

\section{DISCUSSION}

A significant relationship was observed between age and success. A $10 \%$ decrease in $\mathrm{VO}_{2 \max }$ and an increase in body fat, especially in abdominal fat are some complications of aging. In this regard, aging may lower endurance performance, muscular strength, and maximal aerobic and anaerobic power (M Burtscher, Faulhaber, Flatz, Likar, \& Nachbauer, 2006; Hortobágyi et al., 1995). Despite the decline in physiological variables by aging, some believe that the muscular mass of athletes may be relatively maintained during some stages (Martin Burtscher, 2004; Mejuto Hidalgo et al., 2012). The relationship between weight and performance of mountain climbers wasn't significant. The mean weight of Iranian mountain climbers was $74.51 \mathrm{~kg}$ which was higher than those reported in Barbieri et al. (2012). Mountain climbers have not been shown to be able to maintain their body weight at altitudes above 5,000 m (Hamad \& Travis, 2006; Tschöp \& Morrison, 2001; Wagner, 2010). Kayser et al found a $3 \%$ decrease in body weight at altitudes above 5,000 m (Kayser, Acheson, Decombaz, Fern,
\& Cerretelli, 1992). Reported weight of mountain climbers in Zaccagni et al was $76.4 \mathrm{~kg}$ in sea level and $73.5 \mathrm{~kg}$ at altitudes above $4,000 \mathrm{~m}$ (Zaccagni et al., 2014). Long-term residence at high altitudes is often accompanied by a reduced body weight (Wagner, 2010). Ge et al investigated the body weight of two groups including sea level and altitude of 2,200 m residents. After 33 days stay at $4,678 \mathrm{~m}$, a $10.4 \%$ and $2.2 \%$ decrease in body weight reported among sea level and altitude residents, respectively. They also indicated that there was a significant relationship between baseline levels of weight in sea level and weight loss at altitude (Ge et al., 2010). Muscle and fat tissue atrophy appears to be the major cause of weight loss at high altitudes residence. It is becoming clear that males lose a greater amount of weight compared to females in such conditions. Furthermore, during residence at altitudes, heavier individuals lose more weight and are also more susceptible for acute mountain sickness. The manner of climbing, however, may affect the magnitude of weight loss. 
In the present study, BMI showed a non-significant association to success. The mean BMI of Iranian mountain climbers was $23.4 \mathrm{~kg} / \mathrm{m}^{2}$ which was higher than the results reported in Barbieri et al and Bernardi et al (Barbieri et al., 2012; Bernardi, Schneider, Pomidori, Paolucci, \& Cogo, 2006). Zaccagni et al surveyed BMI of mountain climbers in sea level and after expedition to altitudes of 4,000 $\mathrm{m}$. The mean BMI were 24.1 and $23.2 \mathrm{~kg} / \mathrm{m}^{2}$, respectively (Zaccagni et al., 2014). Nourshahi et al investigated the effect of mountaineering on physical fitness of aged people, and mountaineers was reported to have lower BMI (7\%) than their sedentary counterparts (Nourshahi et al., 2011). Another research showed that in high altitudes residents, BMI negatively related to performance at altitude and those who had higher BMI was also more susceptible for hypoxia (Peng et al., 2013). Mountain climbers with higher levels of BMI have been shown to lose more weight in high altitudes. The initial weight have also been found to be significantly related to symptoms of acute mountain sickness (Major \& Doucet, 2004).

There was a significant negative relationship between percent body fat and success of mountain climbers. The mean percent body fat was $12.1 \%$ which was higher than those observed in Sloan et al (7.1\%) (Sloan \& Masali, 1978). Bales et al surveyed percent body fat of mountain climbers before and 24 days after expedition to altitudes. The mean percent body fat were $15.6 \%$ and $13.8 \%$, respectively. They also suggests that top level mountain climbers are in a better position in terms of body composition compared to their lower-ranked counterparts (Bales et al., 1993). The study investigating the magnitude of fat loss before and after expedition showed that subjects lost an average of $9 \%$ body fat at altitudes above $5.000 \mathrm{~m}$ (Kayser et al., 1992). Some other studies have also reported such decrease in percent body fat (Ryepko, 2013; Zaccagni et al., 2014). Although many researchers indicated that altitude-induced weight loss may be attributed to decrease in body fat, the possible advantage of higher percent body fat in maintaining muscle mass has not been evident.

$\mathrm{VO}_{2 \max }$ is considered as a valid indicator of integrated action of cardiorespiratory and muscular systems during exercise and is a major determinant of endurance performance (Impellizzeri \& Marco- ra, 2007). At Everest summit, a $15-20 \%$ decrease in maximal oxygen consumption may occur compared to sea level (Ryepko, 2013). Fifteen percent of this decrease has been shown to occur during first 3 days of residence at altitude (M Burtscher et al., 2006). In the present study, a significant relationship was found between aerobic power and success. The mean aerobic power of male Iranian mountain climbers was $44.25 \mathrm{ml} / \mathrm{kg} / \mathrm{min}$ which was substantially lower than those reported in Kinoshita et al (59.3 $\mathrm{ml} / \mathrm{kg} / \mathrm{min}$ ) (Kinoshita et al., 2000). Wagner (2010) investigated the person who climbed two high summits (Aconcagua and Everest). Reported maximal oxygen consumption was $54.4 \mathrm{ml} / \mathrm{kg} / \mathrm{min}$, Whereas Oelz (1986) estimated the mean of maximal oxygen consumption of mountain climbers 60 $\mathrm{ml} / \mathrm{kg} / \mathrm{min}$ (Oelz et al., 1986; Wagner, 2010). Robach et al found a $59 \%$ decrease in $\mathrm{VO}_{2 \max }$ at an altitude of $7,000 \mathrm{~m}$ by simulating the altitude in special rooms (Robach et al., 2000). Fitness status and type of equipment and tests used may be some possible reasons for these differences. Although, the difference between Iranian climbers and their counterparts in other studies concerning the mean of maximal oxygen consumption depends partially on their fitness level and training method, an aerobic power about $50 \mathrm{ml} / \mathrm{kg} / \mathrm{min}$ appears to be necessary for completion of climbing (Pugh, 1972).

It is assumed that an activity such as rock climbing depends largely on anaerobic power. Mermier et al showed a significant relationship between anaerobic power and motor performance of rock climbers (Mermier, Janot, Parker, \& Swan, 2000). Unlike the aerobic power which decreases exponentially during climbing at altitude, anaerobic performance remains almost unchanged (M Burtscher et al., 2006; Cerretelli, 1992). If the residence time period at altitudes above $5,200 \mathrm{~m}$ isn't more than 5 weeks, possibly no change will occur in anaerobic power (M Burtscher et al., 2006; Shephard \& Astrand, 1992). Whilst the aerobic power may decrease (approximately 25\%) due to hypoxia following 3 weeks of residence at altitude, and the decrease may be related to muscular atrophy (Cerretelli, 1992).

A significant relationship was found between jumping performance and success. Few studies have been done in this context, hence, limited information exists concerning explosive power of mountain 
climbers. In this regard, Ryepko stated that technical rock climbing require higher levels of explosive power than speed climbing (Ryepko, 2013).

Based on results, strength of the lower body significantly related to success of mountain climbers. According to the closed kinetic chain concept, the strength of thigh muscles is vital for controlling lower segments of the body and also preventing injury (Jullien et al., 2008). Additionally, strength and power are considered the two essential factors determining the success in sport events such as mountain climbing. Mermier et al investigated the relationship between isokinetic strength of knee flexors and extensors and shoulder adductors with motor performance of rock climbers. The mentioned variables significantly related to motor performance in rock climbing (Mermier et al., 2000). Accordingly, Grant et al and Mermier et al believe that increase in strength and power is crucial for rock climbers. In mountain climbing, increased strength is accompanied by an enhanced performance (Grant et al., 2001; Mermier et al., 2000). Regarding significant relationship between lower body strength with success in mountain climbing, lower body muscular strength appears to be important to optimize performance in altitude.

The present study showed a significant relationship between torso and upper body muscular endurance with success of mountain climbers. Because of carrying heavy backpacks during long distances, mountain climbers require muscular endurance in torso and upper body. Many researchers believe that

\section{REFERENCES}

1. Bales, B., Hackney, A.C., Coyne, J., Shaw, E., McAninch, G., Kramer, A., \& Brownsberger, R. (1993). Mountaineering sojourn: effects on body composition of prolonged exposure to high altitude in a cold environment. Journal of Wilderness Medicine, 4(1), 32-39.

2. Barbieri, D., Zaccagni, L., Cogo, A., \& Gualdi-Russo, E. (2012). Body composition and somatotype of experienced mountain climbers. High altitude medicine \& biology, 13(1), 46-50.

3. Beam, W., \& Adams, G. (2013). Exercise physiology laboratory manual: McGraw-Hill Higher Education. the muscular endurance of shoulder and forearm is more advantageous compared to some anthropometric characteristics in rock climbing performance (Sheel, 2004). Although limited data are available on endurance performance at high altitudes, however, scientific evidence indicated that continued activity and proper nutrition may contribute to optimal endurance performance at high altitudes (Shephard \& Astrand, 1992).

\section{CONCLUSION}

In summary, the results of the present study support the importance of some physiological, physical and anthropometric traits including aerobic power, anaerobic power, explosive power, lower body strength, upper body and torso muscular endurance, age and percent body fat because of their relationship with success of mountain climbers. Iranian mountain climbers have also been shown to have lower aerobic power and higher levels of BMI and percent body fat compared to their counterparts in some other countries. As discussed earlier, there is a significant relationship between BMI and percent body fat with performance in altitudes. Accordingly, great attention must be paid to aforementioned factors for optimizing performance. Collectively, the results demonstrate the superiority of bio-motor traits over anthropometric traits for successful climbing.

4. Bernardi, L., Schneider, A., Pomidori, L., Paolucci, E., \& Cogo, A. (2006). Hypoxic ventilatory response in successful extreme altitude climbers. European Respiratory Journal, 27(1), 165-171.

5. Brzycki, M. (1993). Strength testing-predicting a one-rep max from reps-to-fatigue. Journal of Physical Education, Recreation \& Dance, 64(1), 88-90.

6. Burtscher, M. (2004). Exercise Capacity for Mountaineering: How Much Is Necessary? Research in Sports Medicine, 12(4), 241-250.

7. Burtscher, M., Faulhaber, M., Flatz, M., Likar, R., \& Nachbauer, W. (2006). Effects of short-term ac- 
climatization to altitude $(3200 \mathrm{~m})$ on aerobic and anaerobic exercise performance. International journal of sports medicine, 27(08), 629-635.

8. Cerretelli, P. (1992). Muscle energetics and ultrastructure in chronic hypoxia. Respiration, 59(Suppl. 2), 24-29.

9. Cheung, W.W., Tong, K.K., Morrison, A.B., Leung, R.W., Kwok, Y.-L., \& Wu, S. (2011). Anthropometrical and physiological profile of Chinese elite sport climbers. Medicina Sportiva, 15(1), 23.

10. Claessens, A., Lefevre, J., Beunen, G., \& Malina, R. (1999). The contribution of anthropometric characteristics to performance scores in elite female gymnasts. Journal of Sports Medicine and Physical Fitness, 39(4), 355.

11. Daniels, J. (1979). Altitude and athletic training and performance. The American journal of sports medicine, 7(6), 371-373.

12. Ge, R., Wood, H., Yang, H., Liu, Y., Wang, X., \& Babb, T. (2010). The body weight loss during acute exposure to high-altitude hypoxia in sea level residents. Sheng li xue bao:[Acta physiologica Sinica], 62(6), 541-546.

13. Grant, S., Hasler, T., Davies, C., Aitchison, T., Wilson, J., \& Whittaker, A. (2001). A comparison of the anthropometric, strength, endurance and flexibility characteristics of female elite and recreational climbers and non-climbers. Journal of sports sciences, 19(7), 499-505.

14. Gualdi-Russo, E., \& Zaccagni, L. (2001). Somatotype, role and performance in elite volleyball players. Journal of Sports Medicine and Physical Fitness, 41(2), 256.

15. Hamad, N., \& Travis, S.P. (2006). Weight loss at high altitude: pathophysiology and practical implications. European journal of gastroenterology \& hepatology, 18(1), 5-10.

16. Hannon, J.P., Shields, J., \& Harris, C.W. (1969). Anthropometric changes associated with high altitude acclimatization in females. American journal of physical anthropology, 31(1), 77-83.

17. Hortobágyi, T., Zheng, D., Weidner, M., Lambert, N.J., Westbrook, S., \& Houmard, J.A. (1995). The influence of aging on muscle strength and muscle fiber characteristics with special reference to eccentric strength. The Journals of Gerontology Series A: Biological Sciences and Medical Sciences, 50(6), B399-B406.
18. Impellizzeri, F.M., \& Marcora, S.M. (2007). The physiology of mountain biking. Sports Medicine, 37(1), 59-71.

19. Jackson, A.S., \& Pollock, M.L. (1978). Generalized equations for predicting body density of men. British journal of nutrition, 40(03), 497-504.

20. Jullien, H., Bisch, C., Largouët, N., Manouvrier, C., Carling, C. J., \& Amiard, V. (2008). Does a short period of lower limb strength training improve performance in field-based tests of running and agility in young professional soccer players? The Journal of Strength \& Conditioning Research, 22(2), 404-411.

21. Kayser, B., Acheson, K., Decombaz, J., Fern, E., \& Cerretelli, P. (1992). Protein absorption and energy digestibility at high altitude. Journal of Applied Physiology, 73(6), 2425-2431.

22. Kemmler, W., Roloff, I., Baumann, H., Schöffl, V., Weineck, J., Kalender, W., \& Engelke, K. (2006). Effect of exercise, body composition, and nutritional intake on bone parameters in male elite rock climbers. International journal of sports medicine, 27(08), 653-659.

23. Kinoshita, N., Yamazaki, H., Onishi, S., Oguma, Y., Katsukawa, F., \& Horii, M. (2000). Physiological profile of middle-aged and older climbers who ascended Gasherbrum II, an 8035-m Himalayan peak. The Journals of Gerontology Series A: Biological Sciences and Medical Sciences, 55(11), M630-M633.

24. Major, G.C., \& Doucet, E. (2004). Energy intake during a typical Himalayan trek. High altitude medicine \& biology, 5(3), 349-363.

25. Mejuto Hidalgo, G., Calleja González, J., Lekue Gallano, J.A., Leibar Mendarte, X., Gárate Ara, R. M., Emparanza Knörr, J.I., . . Terrados Cepeda, N. (2012). Physiological and kinanthropometrical parameters of an elite climber. Single case study. Archives of Budo.

26. Mermier, C.M., Janot, J.M., Parker, D.L., \& Swan, J.G. (2000). Physiological and anthropometric determinants of sport climbing performance. British journal of sports medicine, 34(5), 359-365.

27. Nourshahi, M., Abdoli, B., Rajaeian, A.R., Rahmani, H., Zahedi, H., Arefirad, T., \& Kaviyani, M. (2011). Effects of Mountaineering on Physical Fitness and Quality of Life in Aged People. World Journal of Sport Sciences, 5(3), 149-157. 
28. Oelz, O., Howald, H., Di Prampero, P., Hoppeler, H., Claassen, H., Jenni, R., . . . Veicsteinas, A. (1986). Physiological profile of world-class high-altitude climbers. Journal of Applied Physiology, 60(5), 1734-1742.

29. Peng, Q.-q., Basang, Z., Cui, C.-y., Li, L., Qian, J., Gesang, Q., ... Dawa, P. (2013). Physiological responses and evaluation of effects of BMI, smoking and drinking in high altitude acclimatization: a cohort study in Chinese Han young males. PloS one, 8(11), e79346.

30. Pugh, L. (1972). Maximum oxygen intake in Himalayan mountaineers. Ergonomics, 15(2), 133-137.

31. Robach, P., Déchaux, M., Jarrot, S., Vaysse, J., Schneider, J.C., Mason, N. P., . . Richalet, J.-P. (2000). Operation Everest III: role of plasma volume expansion on $\mathrm{V}^{\cdot} \mathrm{o} 2$ max during prolonged high-altitude exposure. Journal of Applied Physiology, 89(1), 29-37.

32. Ryepko, O. (2013). Morphological characteristics of elite athletes, specializing in speed climbing, climbing and alpinism. Pedagogics, psychology, medical-biological problems of physical training and sports 12, 67-71.

33. Sheel, A. (2004). Physiology of sport rock climbing. British journal of sports medicine, 38(3), 355359.

34. Shephard, R.J., \& Astrand, P.O. (1992). Endurance in Sport. Medicine \& Science in Sports \& Exercise, 24(12), 1413.

35. Sloan, A., \& Masali, M. (1978). Anthropometry of Sherpa men. Annals of human biology, 5(5), 453-458.

36. Tschöp, M., \& Morrison, K. M. (2001). Weight loss at high altitude Hypoxia (pp. 237-247): Springer.

37. Wagner, D.R. (2010). Body composition and hematological changes following ascents of Mt. Aconcagua and Mt. Everest. Aviation, space, and environmental medicine, 81(11), 1045-1048.

38. Zaccagni, L., Barbieri, D., Cogo, A., \& Gualdi-Russo, E. (2014). Anthropometric and Body Composition Changes during Expeditions at High Altitude. High altitude medicine \& biology, 15(2), 176--182. 


\section{ZUSAMMENHANG VON ANTHROPOMETRISCHEN, PHYSIOLOGISCHEN UND PHYSISCHEN EIGENSCHAFTEN UND DES ERFOLGS VON SPITZENALPINISTEN}

\section{Zusammenfassung}

Ziel dieser Untersuchung war es, die anthropometrischen, physiologischen und physischen Eigenschaften von Spitzenalpinisten sowie die Verbindung zwischen diesen Eigenschaften und dem Erfolg im Alpinismus zu erkunden. Achtunddreißig Spitzenalpinisten aus Iran (Größe $178.68+/-5.77 \mathrm{~cm}$, Body-Mass-Index $23.4+/-2.78 \mathrm{~kg} / \mathrm{m}^{2}$, Alter $31.26+/-6.93$ Jahre) wurden in Hinsicht auf bestimmte anthropometrische, physiologische und physische Variablen beurteilt. Gemessen wurden Größe, Gewicht sowie Länge und Umfang der Extremitäten. Der Körperfettanteil wurde durch Messung der Hautfaltendicke an 3 Körperstellen bestimmt. Die aerobe Kraft wurde mit Hilfe eines Lauftests in der Dauer von 12 Minuten eingeschätzt, die anaerobe Kraft mit Hilfe eines anaeroben Step-Tests. Die Performanzen von Hochsprung und Weitsprung wurden mit Hilfe des Sargent-Tests und des Weitsprungs aus dem Stand beurteilt. Ein Sprint-Test in der Länge von 40 Yard (36.3 Meter) wurde für die Geschwindigkeitseinschätzung verwendet, die Muskelausdauer von Rumpf und Oberkörper wurde mit Hilfe von Tests mit Bauchmuskelübungen beurteilt. Die Summe der Ergebnisse in Verbindung mit Sportleistungen wurde als Kriterium für die Einschätzung des Erfolgs bei Alpinisten gesehen. Anthropometrische Eigenschaften (nur Alter und Körperfettanteil) zeigten eine schwache positive Verbindung $(\mathrm{p}<0.05)$ mit Erfolg. Relativ starke Verbindungen wurden zwischen physiologischen und physischen Eigenschaften festgestellt einschließlich der aeroben $\operatorname{Kraft}(\mathrm{p}<0.01)$, der anaeroben Kraft $(\mathrm{p}<0.01)$, des Hochsprungs $(\mathrm{p}<0.05)$, der Kraft des Unterkörpers $(\mathrm{p}<0.01)$ und der Ausdauer der Rumpfmuskel $(\mathrm{p}<0.05)$ und der Muskel des Oberkörpers $(\mathrm{p}<0.01)$ und des Erfolgs der Alpinisten. Die Ergebnisse weisen auf die Bedeutung von physiologischen und physischen Eigenschaften im Vergleich zu anthropometrischen Eigenschaften der Alpinisten hin und heben hervor, dass erfolgreicher Alpinismus in bedeutendem Maße von den oben angeführten Eigenschaften abhängig ist.

Schlüsselwörter: HÖHE ÜBER DEM MEERESSPIEGEL / ALPINISMUS / PHYSIOLOGISCHE EIGENSCHAFTEN / LEISTUNG

The authors would like to thank the I.R. Iran Mountaineering \& Sport Climbing Federation and all mountain climbers for their gracious collaboration.

Received: 19.11.2016.

Accepted: 10.04.2017. 


\title{
ПОВЕЗАНОСТ АНТРОПОМЕТРИЈСКИХ, ФИЗИОЛОШКИХ И ФИЗИЧКИХ КАРАКТЕРИСТИКА И УСПЕШНОСТИ ВРХУНСКИХ АЛПИНИСТА
}

\author{
Хамид Арази, Тахминех Саеди, Мани Изади \\ Универзитет Гуилан, Департман физиологије вежбања, Иран
}

\begin{abstract}
Сажетак
Циљ овог истраживања је био да се испитају антропометријске, физиолошке и физичке карактеристике врхунских алпиниста, као и веза између ових карактеристика и успеха у алпинизму. Тридесет осам врхунских иранских алпиниста (висина $178.68 \pm 5.77 \mathrm{~cm}$, индекс телесне масе $23.4 \pm 2.78 \mathrm{~kg} / \mathrm{m}^{2}$ и старости $31.26 \pm 6.93$ година) је оцењивано у погледу одређених антропометријских, физиолошких и физичких варијабли. Тако су мерене висина, тежина, као и дужина и обим екстремитета. Проценат телесне масти је одређен путем мерења дебљине кожног набора на 3 места. Аеробна снага је процењивана помоћу теста трчања у трајању од 12 минута, анаеробна снага је утврђивана помоћу анаеробног степ теста, перформансе скока увис и скока у даљ су оцењиване помоћу теста суножног скока увис (Сариен $\overline{\mathcal{u}} \overline{\boldsymbol{u} e c} \overline{\mathcal{u}})$ и теста скока удаљ из места, спринт тест на 40 јарди (36.6 метара) коришћен је да се оцени брзина, а издржљивост мишића трупа и горњег дела тела је оцењивана помоћу тестова са трбушњацима и склековима. 3ठир резултата повезаних са спортским постигнућима сматран је критеријумом за оцењивање успеха код алпиниста. Антропометријске карактеристике (једино године старости и проценат телесне масти) показале су слабу позитивну повезаност $(\mathrm{p}<0.05)$ са успешношћу. Док су релативно јаке везе нађене између физиолошких и физичких карактеристика, укључујући аеробну снагу ( $<0.01)$, анаеробну снагу $(\mathrm{p}<0.01)$, скок увис $(\mathrm{p}<0.05)$, снагу доњег дела тела $(\mathrm{p}<0.01)$ и издржљивост мишића трупа $(\mathrm{p}<0.05)$ и горњег дела тела $(\mathrm{p}<0.01)$ и успеха алпиниста. Резултати указују на значај физиолошких и физичких карактеристика у поређењу са антропометријским особинама алпиниста, као и на то да успешно пењање у великој мери зависи од горе наведених карактеристика.
\end{abstract}

КљУчне речи: НАДМОРСКА ВИСИНА / АЛПИНИЗАМ / ФИЗИОЛОШКЕ КАРАКТЕРИСТИКЕ / УЧИНАК

\section{УВОД}

Доказано је да врхунски спортисти треба да имају посебне антропометријске, физиолошке и физичке карактеристике које су повезане са њиховим спортот. Сходно томе, поседовање специфичне физичке грађе, као и врхунских физиолошких и физичких способности, може се сматрати кључним факторима за успех у спортским догађајима. Свест о способностима које су неопходне за спорт је важна и идентификација талената на основу којих се може повећати могућност успеха у спортским догађајима. Стога, главна и најважнија обавеза тренера, стручњака и консултаната је откривање талената на основу фактора који су неопходни у сваком спорту (Barbieri, Zaccagni, Cogo, \& Gualdi-Russo, 2012; Claessens, Lefevre, Beunen, \& Malina, 1999).

Разумевање значаја природе, ситуација, као и потребних антропометријских и физиолошких карактеристика сваког спорта је од кључне важности за оптимизацију учинка. Тренажни програми се стога морају планирати у односу на те варијабле. Недостатак пажње посвећене неопходним особинама спорта може довести до губљења времена и средстава (Cheung, et al., 2011; Gualdi-Russo \& Zaccagni, 2001). Наравно, такве особине могу имати улогу у спортском успеху. Питање је 
да ли ове особине функционишу у сродним спортовима.

У алпинизам, који је првобитно сматран као рекреативна активност, уведене су неке напредне технике и стратегије за унапређење здравља током времена (Grant, et al., 2001; Kemmler, et al., 2006). Међународни савет за такмичарски алпинизам (ICC) је такође заслужан за организовање такмичарског спортског алпинизма (Sheel, 2004). Занимљиво је напоменути да је након одржавања Олимпијских игара у Мексико Ситију, много пажње посвећено надморској висини и учинку у таквим условима (Daniels, 1979).

Једно истраживање је спроведено са нагласком на антропометријским променама које су код 8 жена изазване дуготрајним излагањем великој надморској висини $(4.297 \mathrm{~m})$. Аутори су приметили значајне промене у проценту телесне масти и обиму екстремитета, без промене у телесној маси. Резултати су показали смањени проценат телесне масти током боравка на великој надморској висини (Hannon, Shields, \& Harris, 1969).

У другом истраживању испитиване су промене у телесном саставу и антропометријским варијаблама код 18 испитаника (10 мушкараца и 8 жена). Промене су разматране у погледу 3 фазе (пре напуштања висине нивоа мора, током пењања и након повратка на висину нивоа мора). Мушкарци су показали весће смањење процента телесне масти у односу на жене. Код мушкараца, основне вредности нивоа масе телесне масти су позитивно, односно негативно повезане са смањењем масе телесне масти и масе без масноћа (Zaccagni, Barbieri, Cogo, \& Gualdi-Russo, 2014).

Студија случаја је спроведена на алпинисти који је ишао у поход на два планинска врха (Аконкагва - 6.962m и Еверест - 8.848m). Физичке промене су мерене неколико дана након одласка. Резултати су показали смањење од $3 \%$ и $21,9 \%$ телесне масе и процента телесне масти после експедиције на врх Аконкагва. Слично томе, смањење од $6.9 \%$ и $41 \%$ у поменутим варијаблама показало се након експедиције на Еверест. Изгледа да је могући узрок већих физичких промена дуже излагање већој надморској висини приликом експедиције на Еверест (Wagner, 2010).

Ипак, иако су многа истраживања спроведена на алпинистима, већина њих је испитивала ефекте хипоксије на учинак на висини нивоа мора и надморској висини, а мање пажње је посвећено антропометријским, физиолошким и физичким карактеристикама и њиховој повезаности са учинком. Тако је ова студија имала за циљ да истражи антропометријске, физиолошке и физичке карактеристике врхунских алпиниста, као и утицај ових карактеристика на успех врхунских алпиниста.

\section{МЕТОД}

\section{Узорак испитаника}

Узорак се састојао од 38 врхунских алпиниста из Ирана који се професионално баве планинарењем и у просеку изведу један успон на врхове изнад 3.000 м недељно. Добијено је етичко одобрење институција. Након тога, испитаници су обавештени о протоколу.

\section{Узорак варијабли и мерења}

\section{Анирройометиријска ирроцена}

Антропометријске варијабле, укључујући висину, дужину доњег дела тела, као и обим груди, струка, бутина и мишића листа мерени су са прецизношћу од $0.1 \mathrm{~cm}$. Тежина је такође мерена са прецизношћу од $0.1 \mathrm{~kg}$ помоћу дигиталне ваге. Индекс телесне масе је израчунат дељењем тежине $(\mathrm{kg})$ са висином $(\mathrm{m})$ на квадрат $(\mathrm{kg} / \mathrm{m} 2)$. Поткожне масне наслаге су мерене на 3 места (груди, абдомен и бутине) коришћењем Вогел калипера (произведен у Немачкој), а затим је израчунат проценат телесне масти помоћу Џекасон и Полок једначине (Beam \& Adams, 2013; Jackson \& Pollock, 1978).

\section{Физиолошка ирроцена}

У овом истраживању коришћен је тест трчања у трајању од 12 минута како би се утврдила максимална аеробна снага. Од испитаника је тражено да трче највећом могућом брзином 12 минута и $\mathrm{VO}_{2 \max }$ је оцењиван помоћу следеће једначине како би се проценила аеробна снага (Веам \& Adams, 2013):

$\mathrm{VO}_{2 \text { мах }}(\mathrm{ml} / \mathrm{kg} / \mathrm{min})=($ Растојање $\left.\mathrm{y} \mathrm{km})-0.505\right)$ $\div 0.0447$

Анаеробна снага је утврђена помоћу анаеробног теста корака. Резултати су израчунати коришћењем следеће једначине (Beam \& Adams, 2013):

$$
\mathrm{M}-\mathrm{Anp}(\mathrm{W})=\left({ }^{+} \mathrm{W} \times 1.33\right) \div \mathrm{t}
$$


M-Anp: средња анаеробна снага; ${ }^{+} \mathrm{W}$ : позитиван рад (сила $\times$ растојање); сила: телесна маса $(\mathrm{N})$; растојање $=$ висина клупе $(0.4 \mathrm{~cm}) \times$ кораци $($ за 1 минут); 1.33: фактор претварања позитивног рада у укупан рад (N.м;j); t: $60 \mathrm{~s}$

\section{Процена мотиоричких сйособносиии}

Учинак у скоку увис и скоку удаљ је оцењиван помоћу Саргент теста за скок увис и теста скока удаљ из места, као и путем скала на зиду и тлу, за сваки скок. Додатно, брзина је процењена путем спринт теста на 40 јарди. Време завршетка теста је бележено помоћу Q\&Q хронометра. Тест притиска ногом је коришћен за процену максималне снаге мишића доњих екстремитета, тако да су испитаници извршавали максимална понављања све до отказа. Затим је израчунаван 1РМ коришћењем једначине Брзицког (Brzycki, 1993). Teстови са трбушњацима и склековима су коришће- ни за одређивање мишићне издржљивости трупа, односно горњег дела тела. У тесту са склековима максимална понављања су извођена до отказа. Испитаницима је наложено да ураде трбушњаке за 1 минут, а бележен је број понављања.



Неке спортске дисциплине, у односу на своју природу, не могу дозволити квантификацију спортских резултата, а углавном ни не постоји одређено такмичење за њих. Због тога је тешко обавити процену и то је прилично очигледно у алпинизму. У складу с тим, након консултација са стручњацима из сродних области и прегледа урађених истраживања, успех алпиниста је разматран на основу резултата које одређује Савез, као и целокупних њихових резултата у алпинизму. Вредновање је представљено у табели 1.

Табела 1. Метод вредновања успеха на основу достигнућа елитних алпиниста

\begin{tabular}{ccc}
\hline Висина $(\mathbf{m})$ & Одговара рангу & Резултат \\
\hline $8501-8848$ & 1. Светски ранг & 100 \\
$8101-8500$ & 2. Светски ранг & 90 \\
$7901-8100$ & 3. Светски ранг & 85 \\
$7601-7900$ & 1. Азијски ранг & 80 \\
$7301-7600$ & 2. Азијски ранг & 70 \\
$7001-7300$ & 3. Азијски ранг & 65 \\
$6601-7000$ & 1. национални ранг & 60 \\
$6101-6600$ & 2. национални ранг & 50 \\
$5501-6100$ & 3. национални ранг & 45 \\
\hline
\end{tabular}

\section{Обрада података}

Нормалност дистрибуције података је утврђена помоћу Колмогоров-Смирнов теста, а Пирсонов коефицијент корелације је коришћен за утврђивање повезаности антропометријских, физиолошких и физичких карактеристика са успехом. Све статистичке анализе су спроведене помоћу SPSS 20. Ниво значајности је постављен на $\mathrm{p}<0.05$.

\section{РЕЗУЛТАТИ}

Дескриптивна статистика антропометријских, физиолошких и физичких карактеристика испитаника, као и њихова повезаност са успехом, приказани су у табели 2. 
Табела 2. Повезаност између успеха алпиниста и њихових антропометријских, физиолошких и моторичких карактеристика

\begin{tabular}{lccc}
\hline \multicolumn{1}{c}{ Варијабле } & АС \pm СД & r & p \\
\hline Узраст (године) & $31.26 \pm 6.93$ & 0.37 & $0.01^{*}$ \\
Телесна маса $(\mathbf{k g})$ & $74.51 \pm 7.80$ & 0.15 & 0.18 \\
Телесна висина $(\mathbf{c m})$ & $178.68 \pm 5.77$ & 0.03 & 0.42 \\
Дужина ногу $(\mathbf{c m})$ & $102.72 \pm 4.99$ & 0.06 & 0.34 \\
БМИ $\left(\mathbf{k g} / \mathbf{m}^{2}\right)$ & $23.40 \pm 2.78$ & 0.10 & 0.25 \\
Масно ткиво (\%) & $12.10 \pm 0.039$ & -0.28 & $0.04^{*}$ \\
Обим груди (cm) & $95.30 \pm 6.75$ & 0.23 & 0.07 \\
Обим струка (cm) & $85.24 \pm 6.34$ & 0.02 & 0.45 \\
Обим натколенице (cm) & $54.86 \pm 4.12$ & 0.22 & 0.08 \\
Обим потколенице (cm) & $37.87 \pm 4.47$ & 0.03 & 0.42 \\
УО, тм1/kg/min & $44.25 \pm 7.37$ & 0.38 & $0.00^{* *}$ \\
Анаеробна моћ $(\mathbf{W})$ & $389.99 \pm 103.06$ & 0.48 & $0.00^{* *}$ \\
Вертикални одскок (cm) & $44.26 \pm 6.44$ & 0.33 & $0.02^{*}$ \\
Скок удаљ (ст) & $222.18 \pm 18.94$ & 0.04 & 0.40 \\
Трчање на 40 јарди (s) & $8.31 \pm 1.47$ & -0.14 & 0.18 \\
Потисак ногама, 1РМ (kg) & $93.03 \pm 13.97$ & 0.42 & $0.00^{* *}$ \\
Трбушњаци (број понављања) & $43.37 \pm 13.48$ & 0.31 & $0.02^{*}$ \\
Склекови (број понављања) & $37.26 \pm 19.95$ & 0.38 & $0.00^{* *}$ \\
\hline
\end{tabular}

${ }^{*} \mathrm{P} \leq 0.05 ;{ }^{* *} \mathrm{P} \leq 0.01$

\section{ДИСКУСИЈА}

Значајна повезаност је уочена између година старости и успеха. Смањење од $10 \%$ у $\mathrm{VO}_{2 \text { мах }}$ и повећање телесне масти, нарочито у абдоминалној масноћи, неке су од компликација које настају услед старења. У том погледу, старење може умањити учинак издржљивости, мишићне снаге, као и максималне аеробне и анаеробне снаге (Burtscher, Faulhaber, Flatz, Likar, \& Nachbauer, 2006; Hortobágyi, et al., 1995). Упркос опадању физиолошких варијабли током старења, неки сматрају да се мишићна маса код спортиста може релативно задржати током неких фаза (Burtscher, 2004; Mejuto Hidalgo, et al., 2012). Повезаност између телесне масе и учинка алпиниста није била значајна. Средња телесна маса иранских алпиниста износила је $74.51 \mathrm{~kg}$, што је више од оне коју су навели Барбиери и сарадници (Barbieri, et al., 2012). Алпинисти се нису показали способним да одрже своју телесну масу на надморским висинама већим од 5.000 m (Hamad \& Travis, 2006; Tschöp \& Morrison, 2001; Wagner, 2010). Кајзер и сарадници су открили смањење од $3 \%$ у телесној маси на надморским висинама изнад $5.000 \mathrm{~m}$ (Kayser,
Acheson, Decombaz, Fern, \& Cerretelli, 1992). Teлесна маса алпиниста коју су пријавили Закањи и сарадници износила је $76.4 \mathrm{~kg}$ на висини нивоа мора и $73.5 \mathrm{~kg}$ на надморским висинама изнад $4.000 \mathrm{~m}$ (Zaccagni et al., 2014). Дуготрајни боравак на великим надморским висинама је често праћен смањеном телесном масом (Wagner, 2010). Ге и сарадници (Ge, Wood, Yang, Liu, Wang, \& Babb, 2010) су испитивали телесну масу на великим надморским висинама код две групе које су обухватале становнике на висини нивоа мора и надморској висини од $2.200 \mathrm{~m}$. Након 33 дана боравка на висини од $4.678 \mathrm{~m}$, смањење од $10.4 \%$, односно $2.2 \%$ је пријављено код становника на висини нивоа мора и надморској висини. Они су такође указали на то да постоји значајна повезаност између основних вредности нивоа тежине на висини нивоа мора и губитка тежине на надморским висинама (Ge, et al., 2010). Чини се да је главни узрок губитка тежине при боравку на великим надморским висинама атрофија мишића и масног ткива. Постаје јасно да мушкарци губе већу количину телесне тежине у поређењу са женама у таквим 
условима. Осим тога, током боравка на надморским висинама, појединци који су тежи губе више телесне тежине и такође су подложнији акутним планинским болестима. Начин пењања, међутим, може утицати на количину губитка тежине.

У овој студији, БМИ није показао значајну повезаност са успехом. Средња вредност индекса телесне масе (БМИ) иранских алпиниста је износила $23.4 \mathrm{~kg} / \mathrm{m}^{2}$ што је више од резултата које су навели Барбиери и сарадници, као и Бернарди и сарадници (Barbieri et al., 2012; Bernardi, Schneider, Роміdori, Paolucci, \& Cogo, 2006). Закањи и сарадници су истраживали индекс телесне масе (БМИ) алпиниста на нивоу мора и након експедиције на надморске висине од $4.000 \mathrm{~m}$. Средња вредност БМИ је износила 24.1, односно $23.2 \mathrm{~kg} / \mathrm{m}^{2}$ (Zaccagni, et al., 2014). Ноуршахи и сарадници су испитивали утицај планинарења на физичку кондицију старијих људи, а пријављено је да алпинисти имају мањи БМИ (7\%) у односу на њихове седентарне колеге (Nourshahi, et al., 2011). Друга истраживања су показала да је код становника на великим надморским висинама, БМИ негативно повезан са учинком на надморској висини, а они који су имали већи БМИ су такође били осетљивији на хипоксију (Peng, et al., 2013). Алпинисти са вишим нивоима БМИ су показали да губе већу телесну масу на великим надморским висинама. Такође је откривено да је почетна тежина значајно повезана са симптомима акутне планинске болести (Major \& Doucet, 2004).

Постојала је значајна негативна повезаност између процента телесне масти и успеха алпиниста. Средњи проценат телесне масти је износио $12.1 \%$ што је више него проценат који је примећен код Слоан и сарадника (7.1\%) (Sloan \& Masali, 1978). Бејлс и сарадници су испитивали проценат телесне масти код алпиниста пре и 24 дана после експедиције на надморским висинама. Средњи проценат телесне масти износио је $15.6 \%$, односно $13.8 \%$. Они такође указују на то да су врхунски алпинисти у бољем положају у смислу телесног састава у поређењу са њиховим ниже рангираним колегама (Bales, et al.,1993). Студија која је истраживала количину губитка масти пре и после експедиције је показала да су испитаници изгубили у просеку 9\% телесне масти на надморским висинама изнад $5.000 \mathrm{~m}$ (Kayser, et al., 1992). Неке друге студије су такође пријавиле такво смањење процента телесне масти (Ryepko, 2013; Zaccagni, et al.,
2014.). Мада су многи истраживачи указали да се губитак телесне тежине изазван надморском висином може приписати смањењу телесне масти, могућа предност већег процента телесне масти у одржавању мишићне масе није очигледна.

$\mathrm{VO}_{2 \max }$ се сматра валидним показатељем интегрисаног деловања кардио-респираторног и мишићног система током вежбања и главна је одредница учинка издржљивости (Impellizzeri \& Marcora, 2007). На врху Еверест, смањење од 15$20 \%$ у максималној потрошњи кисеоника може настати у односу на ниво мора (Ryepko, 2013). Показало се да се петнаест процената овог смањења догоди током прва 3 дана боравка на надморској висини (Burtscher, et al., 2006). У овој студији, значајна веза је откривена између аеробне снаге и успеха. Средња аеробна снага иранских алпиниста је износила $44.25 \mathrm{ml} / \mathrm{kg} /$ мin што је знатно ниже од оне коју су пријавили Киношита и сарадници (59.3 $\mathrm{ml} / \mathrm{kg} / \mathrm{min}$ ) (Kinoshita et al., 2000). Вагнер (Wagner, 2010) је испитивао особу која се попела на два висока планинска врха (Аконкагва и Еверест). Нађена максимална потрошња кисеоника је износила $54.4 \mathrm{ml} / \mathrm{kg} / \mathrm{min}$, док је Оелз (1986) проценио средњу вредност максималне потрошње кисеоника код алпиниста од $60 \mathrm{ml} / \mathrm{kg} / \mathrm{min}$ (Oelz, et al.,1986; Wagner, 2010). Робах и сарадници су открили смањење од 59\% у $\mathrm{VO}_{2 \max }$ на надморској висини од 7.000 метара, помоћу симулације висине у посебним просторијама (Robach, et al., 2000). Стање физичке спремности и врста опреме, као и тестови који су коришћени могу бити неки од могућих разлога ових разлика. Иако разлика између иранских алпиниста и њихових колега у другим студијама о средњој вредности максималне потрошње кисеоника зависи делимично од нивоа њихове физичке спремности и метода тренинга, aеробна снага од око $50 \mathrm{ml} / \mathrm{kg} / \mathrm{min}$ је изгледа неопходна како би се завршило пењање (Pugh, 1972).

Претпоставља се да активност попут пењања уз стену у многоме зависи од анаеробне снаге. Мермиер и сарадници су показали значајну везу између анаеробне снаге и моторичких перформанси алпиниста (Mermier, Janot, Parker, \& Swan, 2000). За разлику од аеробне снаге која опада експоненцијално током пењања на надморској висини, анаеробна перформанса остаје скоро непромењена (Burtscher, et al., 2006;. Cerretelli, 1992). Ако време боравка на висинама изнад $5.200 \mathrm{~m}$ не траје више од 5 недеља, вероватно неће доћи до 
промене у анаеробној снази (Burtscher, et al.,2006; Shephard \& Astrand, 1992). Међутим, аеробна снага се може смањити (око 25\%) услед хипоксије након 3 недеље боравка на надморској висини, а смањење може бити повезано са мишићном атрофијом (Cerretelli, 1992).

Значајна веза је откривена између перформанси скока и успеха. Ниједна студија није спроведена у овом контексту, тако да постоје ограничене информације о експлозивној снази алпиниста. У том смислу, Риепко је навео да техничко пењање уз стену захтева виши ниво експлозивне снаге од брзинског пењања (Ryepko, 2013).

Резултати указују да је снага доњег дела тела значајно повезана са успехом алпиниста. Према концепту затвореног кинетичког ланца, снага мишића бутина је од кључног значаја за контролу доњих делова тела, као и за спречавање повреда (Jullien, et al., 2008). Осим тога, снага и сила се сматрају за два кључна фактора који одређују успех у спортским догађајима, као што је алпинизам. Мермиер и сарадници су истраживали везу између изокинетичке снаге прегибача и опружача колена и мишића примицача рамена и моторичких перформанси пењача уз стене. Наведене варијабле су значајно повезане са моторичким перформансама у пењању уз стену (Mermier, et al., 2000). Сходно томе, Грант и сарадници, као и Мермиер и сарадници верују да је повећање снаге и силе од кључног значаја за пењаче уз стене. У алпинизму, повећана снага је праћена побољшаним учинком (Grant, et al., 2001; Mermier, et al., 2000). Што се тиче значајне повезаности између снаге доњег дела тела и успеха у алпинизму, снага мишића доњег дела тела је изгледа важна за оптимизацију учинка на надморској висини.

Ово истраживање је показало значајну везу између издржљивости мишића трупа и горњег дела

\section{ЛИТЕРАТУРА}

1. Bales, B., Hackney, A.C., Coyne, J., Shaw, E., McAninch, G., Kramer, A., \& Brownsberger, R. (1993). Mountaineering sojourn: effects on body composition of prolonged exposure to high altitude in a cold environment. Journal of Wilderness Medicine, 4(1), 32-39. тела и успеха алпиниста. Због ношења тешких ранаца на дугим релацијама, алпинистима је неопходна издржљивост мишића трупа и горњег дела тела. Многи истраживачи верују да мишићна издржљивост рамена и подлактице има више предности у односу на неке антропометријске карактеристике у погледу учинка у пењању уз стене (Sheel, 2004). Иако су подаци који су доступни о перформансама издржљивости на великим надморским висинама ограничени, ипак, научни докази указују да непрекидна активност и правилна исхрана могу допринети оптималном учинку издржљивости на великим надморским висинама (Shephard \& Astrand, 1992).

\section{ЗАКЉУЧАК}

Укратко, резултати ове студије подржавају значај одређених физиолошких, физичких и антрополошких карактеристика, укључујући аеробну снагу, анаеробну снагу, експлозивну снагу, снагу доњег дела тела, мишићну издржљивост горњег дела тела и трупа, године старости и проценат масти у телу, због њихове повезаности са успехом алпиниста. Ирански алпинисти су такође показали да имају мању аеробну снагу, као и више нивое БМИ и процента телесне масти у односу на њихове колеге у неким другим земљама. Као што је раније речено, постоји значајна веза између БМИ и процента телесне масти и учинка на надморским висинама. Сходно томе, велика пажња се мора посветити наведеним факторима за оптимизацију учинка. Колективно, резултати показују супериорност биомоторичких карактеристика у односу на антропометријске карактеристике у погледу успешности алпинизма.

2. Barbieri, D., Zaccagni, L., Cogo, A., \& Gualdi-Russo, E. (2012). Body composition and somatotype of experienced mountain climbers. High altitude medicine \& biology, 13(1), 46-50. 
3. Beam, W., \& Adams, G. (2013). Exercise physiology laboratory manual: McGraw-Hill Higher Education.

4. Bernardi, L., Schneider, A., Pomidori, L., Paolucci, E., \& Cogo, A. (2006). Hypoxic ventilatory response in successful extreme altitude climbers. European Respiratory Journal, 27(1), 165-171.

5. Brzycki, M. (1993). Strength testing-predicting a one-rep max from reps-to-fatigue. Journal of Physical Education, Recreation \& Dance, 64(1), 88-90.

6. Burtscher, M. (2004). Exercise Capacity for Mountaineering: How Much Is Necessary? Research in Sports Medicine, 12(4), 241-250.

7. Burtscher, M., Faulhaber, M., Flatz, M., Likar, R., \& Nachbauer, W. (2006). Effects of short-term acclimatization to altitude $(3200 \mathrm{~m})$ on aerobic and anaerobic exercise performance. International journal of sports medicine, 27(08), 629-635.

8. Wagner, D.R. (2010). Body composition and hematological changes following ascents of Mt. Aconcagua and Mt. Everest. Aviation, space, and environmental medicine, 81(11), 1045-1048.

9. Ge, R., Wood, H., Yang, H., Liu, Y., Wang, X., \& Babb, T. (2010). The body weight loss during acute exposure to high-altitude hypoxia in sea level residents. Sheng li xue bao:[Acta physiologica Sinica], 62(6), 541-546.

10. Grant, S., Hasler, T., Davies, C., Aitchison, T., Wilson, J., \& Whittaker, A. (2001). A comparison of the anthropometric, strength, endurance and flexibility characteristics of female elite and recreational climbers and non-climbers. Journal of sports sciences, 19(7), 499-505.

11. Gualdi-Russo, E., \& Zaccagni, L. (2001). Somatotype, role and performance in elite volleyball players. Journal of Sports Medicine and Physical Fitness, 41(2), 256.

12. Daniels, J. (1979). Altitude and athletic training and performance. The American journal of sports medicine, 7(6), 371-373.

13. Zaccagni, L., Barbieri, D., Cogo, A., \& Gualdi-Russo, E. (2014). Anthropometric and Body Composition Changes during Expeditions at High Altitude. High altitude medicine \& biology, 15(2), 176-182.
14. Impellizzeri, F.M., \& Marcora, S.M. (2007). The physiology of mountain biking. Sports Medicine, $37(1), 59-71$.

15. Jackson, A.S., \& Pollock, M.L. (1978). Generalized equations for predicting body density of men. British journal of nutrition, 40(03), 497-504.

16. Jullien, H., Bisch, C., Largouët, N., Manouvrier, C., Carling, C. J., \& Amiard, V. (2008). Does a short period of lower limb strength training improve performance in field-based tests of running and agility in young professional soccer players? The Journal of Strength \& Conditioning Research, 22(2), 404-411.

17. Kayser, B., Acheson, K., Decombaz, J., Fern, E., \& Cerretelli, P. (1992). Protein absorption and energy digestibility at high altitude. Journal of Applied Physiology, 73(6), 2425-2431.

18. Kemmler, W., Roloff, I., Baumann, H., Schöffl, V., Weineck, J., Kalender, W., \& Engelke, K. (2006). Effect of exercise, body composition, and nutritional intake on bone parameters in male elite rock climbers. International journal of sports medicine, 27(08), 653-659.

19. Kinoshita, N., Yamazaki, H., Onishi, S., Oguma, Y., Katsukawa, F., \& Horii, M. (2000). Physiological profile of middle-aged and older climbers who ascended Gasherbrum II, an 8035-m Himalayan peak. The Journals of Gerontology Series A: Biological Sciences and Medical Sciences, 55(11), M630-M633.

20. Major, G.C., \& Doucet, E. (2004). Energy intake during a typical Himalayan trek. High altitude medicine \& biology, 5(3), 349-363.

21. Mejuto Hidalgo, G., Calleja González, J., Lekue Gallano, J.A., Leibar Mendarte, X., Gárate Ara, R. M., Emparanza Knörr, J.I., . . . Terrados Cepeda, N. (2012). Physiological and kinanthropometrical parameters of an elite climber. Single case study. Archives of Budo.

22. Mermier, C.M., Janot, J.M., Parker, D.L., \& Swan, J.G. (2000). Physiological and anthropometric determinants of sport climbing performance. British journal of sports medicine, 34(5), 359-365.

23. Nourshahi, M., Abdoli, B., Rajaeian, A.R., Rahmani, H., Zahedi, H., Arefirad, T., \& Kaviyani, M. (2011). Effects of Mountaineering on Physical 
Fitness and Quality of Life in Aged People. World Journal of Sport Sciences, 5(3), 149-157.

24. Oelz, O., Howald, H., Di Prampero, P., Hoppeler, H., Claassen, H., Jenni, R., . . . Veicsteinas, A. (1986). Physiological profile of world-class high-altitude climbers. Journal of Applied Physiology, 60(5), 1734-1742.

25. Peng, Q.-q., Basang, Z., Cui, C.-y., Li, L., Qian, J., Gesang, Q., ... Dawa, P. (2013). Physiological responses and evaluation of effects of BMI, smoking and drinking in high altitude acclimatization: a cohort study in Chinese Han young males. PloS one, 8(11), e79346.

26. Pugh, L. (1972). Maximum oxygen intake in Himalayan mountaineers. Ergonomics, 15(2), 133-137.

27. Robach, P., Déchaux, M., Jarrot, S., Vaysse, J., Schneider, J.C., Mason, N. P., . . R Richalet, J.-P. (2000). Operation Everest III: role of plasma volume expansion on $\mathrm{V}^{\cdot} \mathrm{o} 2$ max during prolonged high-altitude exposure. Journal of Applied Physiology, 89(1), 29-37.

28. Ryepko, O. (2013). Morphological characteristics of elite athletes, specializing in speed climbing, climbing and alpinism. Pedagogics, psychology, medical-biological problems of physical training and sports 12, 67-71.

29. Sheel, A. (2004). Physiology of sport rock climbing. British journal of sports medicine, 38(3), 355-359.

30. Shephard, R.J., \& Astrand, P.O. (1992). Endurance in Sport. Medicine \& Science in Sports \& Exercise, 24(12), 1413.
31. Sloan, A., \& Masali, M. (1978). Anthropometry of Sherpa men. Annals of human biology, 5(5), 453-458.

32. Tschöp, M., \& Morrison, K. M. (2001). Weight loss at high altitude Hypoxia (pp. 237-247): Springer.

33. Hamad, N., \& Travis, S.P. (2006). Weight loss at high altitude: pathophysiology and practical implications. European journal of gastroenterology \& hepatology, 18(1), 5-10.

34. Hannon, J.P., Shields, J., \& Harris, C.W. (1969). Anthropometric changes associated with high altitude acclimatization in females. American journal of physical anthropology, 31(1), 77-83.

35. Hortobágyi, T., Zheng, D., Weidner, M., Lambert, N.J., Westbrook, S., \& Houmard, J.A. (1995). The influence of aging on muscle strength and muscle fiber characteristics with special reference to eccentric strength. The Journals of Gerontology Series A: Biological Sciences and Medical Sciences, 50(6), B399-B406.

36. Cerretelli, P. (1992). Muscle energetics and ultrastructure in chronic hypoxia. Respiration, 59(Suppl. 2), 24-29.

37. Cheung, W.W., Tong, K.K., Morrison, A.B., Leung, R.W., Kwok, Y.-L., \& Wu, S. (2011). Anthropometrical and physiological profile of Chinese elite sport climbers. Medicina Sportiva, 15(1), 23.

38. Claessens, A., Lefevre, J., Beunen, G., \& Malina, R. (1999). The contribution of anthropometric characteristics to performance scores in elite female gymnasts. Journal of Sports Medicine and Physical Fitness, 39(4), 355. 


\section{ZUSAMMENHANG VON ANTHROPOMETRISCHEN, PHYSIOLOGISCHEN UND PHYSISCHEN EIGENSCHAFTEN UND DES ERFOLGS VON SPITZENALPINISTEN}

\section{Zusammenfassung}

Ziel dieser Untersuchung war es, die anthropometrischen, physiologischen und physischen Eigenschaften von Spitzenalpinisten sowie die Verbindung zwischen diesen Eigenschaften und dem Erfolg im Alpinismus zu erkunden. Achtunddreißig Spitzenalpinisten aus Iran (Größe $178.68+/-5.77 \mathrm{~cm}$, Body-Mass-Index $23.4+/-2.78 \mathrm{~kg} / \mathrm{m}^{2}$, Alter $31.26+/-6.93$ Jahre) wurden in Hinsicht auf bestimmte anthropometrische, physiologische und physische Variablen beurteilt. Gemessen wurden Größe, Gewicht sowie Länge und Umfang der Extremitäten. Der Körperfettanteil wurde durch Messung der Hautfaltendicke an 3 Körperstellen bestimmt. Die aerobe Kraft wurde mit Hilfe eines Lauftests in der Dauer von 12 Minuten eingeschätzt, die anaerobe Kraft mit Hilfe eines anaeroben Step-Tests. Die Performanzen von Hochsprung und Weitsprung wurden mit Hilfe des Sargent-Tests und des Weitsprungs aus dem Stand beurteilt. Ein Sprint-Test in der Länge von 40 Yard (36.3 Meter) wurde für die Geschwindigkeitseinschätzung verwendet, die Muskelausdauer von Rumpf und Oberkörper wurde mit Hilfe von Tests mit Bauchmuskelübungen beurteilt. Die Summe der Ergebnisse in Verbindung mit Sportleistungen wurde als Kriterium für die Einschätzung des Erfolgs bei Alpinisten gesehen. Anthropometrische Eigenschaften (nur Alter und Körperfettanteil) zeigten eine schwache positive Verbindung $(\mathrm{p}<0.05)$ mit Erfolg. Relativ starke Verbindungen wurden zwischen physiologischen und physischen Eigenschaften festgestellt einschließlich der aeroben $\operatorname{Kraft}(\mathrm{p}<0.01)$, der anaeroben Kraft $(\mathrm{p}<0.01)$, des Hochsprungs $(\mathrm{p}<0.05)$, der Kraft des Unterkörpers $(\mathrm{p}<0.01)$ und der Ausdauer der Rumpfmuskel $(\mathrm{p}<0.05)$ und der Muskel des Oberkörpers $(\mathrm{p}<0.01)$ und des Erfolgs der Alpinisten. Die Ergebnisse weisen auf die Bedeutung von physiologischen und physischen Eigenschaften im Vergleich zu anthropometrischen Eigenschaften der Alpinisten hin und heben hervor, dass erfolgreicher Alpinismus in bedeutendem Maße von den oben angeführten Eigenschaften abhängig ist.

Schlüsselwörter: HÖHE ÜBER DEM MEERESSPIEGEL / ALPINISMUS / PHYSIOLOGISCHE EIGENSCHAFTEN / LEISTUNG

Аутори захваљују Планинарској и алпинистичкој федерацији Ирана и свим испитаницима на њиховој сјајној сарадњи.

Примљен: 19.11.2016.

Прихваћен: 10.04.2017. 